\title{
Research in the Crypts of the Church of Saint Francis of Assisi in Cracow
}

\section{Introduction}

The Church of Saint Francis of Assisi is a part of a monastic complex of the Order of Friars Minor located in the Old Town in Cracow in All Saints Square and in Franciszkańska Street. It was built of brick, with stone in decorative and architectural details. It is oriented, and today it consists of a chancel, a transept, a nave, and three chapels (of Blessed Salomea, of the Passion of Christ, and of Our Lady of Sorrows). It dates back to the thirteenth century, when Friars Minor came to Cracow in 1237 and started building a church that was consecrated in 1269 . Some researchers consider the Cracow Voivode Teodor Gryfit, called Czader, the first founder of this church (Labuda 1983: 369-38I). However, according to Jan Długosz, the founder was a Piast Duke Bolesław v the Chaste (Długosz I864: 463; 1973: 548-549). The oldest, eastern part of the church was built on a plan of a Greek cross (Niewalda, Rojkowska 2006: 8I-I30; 2008: 27I-298). The main body, as it looks today, was most probably added to the eastern cross part in the third quarter of the thirteenth century. In the fifteenth century, the church was extended, prolonging the chancel by two spans and enclosing it from the east with a three-sided apse. At the northern wall of the chancel, a chapel of the guild of carpenters and bricklayers was erected, and in 1674 it was dedicated to Blessed Salomea (Kantak 1937: 56). In the fifteenth century, cloisters were completed, connecting the church, chapels, and monastery building to form a whole. Over the centuries, the church underwent a number of alterations and changed its appearance. These changes were caused by, among others, multiple fires (1 436, I 476, I655, I850). For example, after the fire in 1655 , the interior became baroque and the space was divided into the central nave and a closed chapel in the north (today's Chapel of the Passion of 
Christ). Separation of the northern nave rearranged the space, creating a one-nave church with a transept made of side cross arms.

The most damaging was the fire in 1850 , and restoration after it caused considerable stylistic changes including introduction of neo-Gothic and pseudo-Romanesque elements. Some beautiful polychrome paintings of Stanisław Wyspiański appeared on the church walls, and huge window openings were covered with stained glass by the same author.

\section{The aim and the course of the research}

Recent years have seen a growing interest in opening vaults hidden under church floors. The activities undertaken are not always carried out with proper care and diligence, and the artefacts discovered are not always analysed using specialist techniques. We decided to run a project that would allow to demonstrate the complexity and multifaceted character of research conducted in vaults, and to carry it out on different planes using modern equipment.

We were able to implement this plan thanks to funding from the National Science Centre ${ }^{1}$. Under this project, archaeological research was carried out in 2017 and 2018 in the Church of Saint Francis of Assisi with the aim to locate, inventory, and explore crypts, and particularly to study the burials and grave goods. The work was directed by Professor Anna Drążkowska from the Institute of Archaeology of Nicolaus Copernicus University in Torun, who picked a team of researchers including representatives of many disciplines to fulfil the aims of an interdisciplinary project. Thanks to this, Polish crypts and burials were explored as thoroughly and comprehensively as never before.

Research in the Cracow church posed a great challenge to archaeologists as most crypts were not marked on the floor. This made it possible to test different modern devices and search methods.

During the first stage of research, for cognitive reasons, as many as three different sets of georadar equipment were used for field surveys: a Swedish Ground Explorer (GX) georadar manufactured by Mala/ABM with a monostatic antenna with central frequency of $450 \mathrm{MHz}$ (HDR - High Dynamic Range), a VIY-30oiw set manufactured by a Ukrainian company Transient Technologies with a monostatic antenna with frequency of $300 \mathrm{MHz}$, and a Swedish U-Explorer georadar manufactured by Geoscanners AB, also with a monostatic antenna with nominal frequency of $300 \mathrm{MHz}$. The georadar exploration was carried out in the available

I "Crypts in the Church of Saint Francis of Assisi in Cracow in Interdisciplinary Research" project funded by the National Science Centre as part of the OPUS I2 competition (registration number: 2016/23/B/HS3/orgio). 


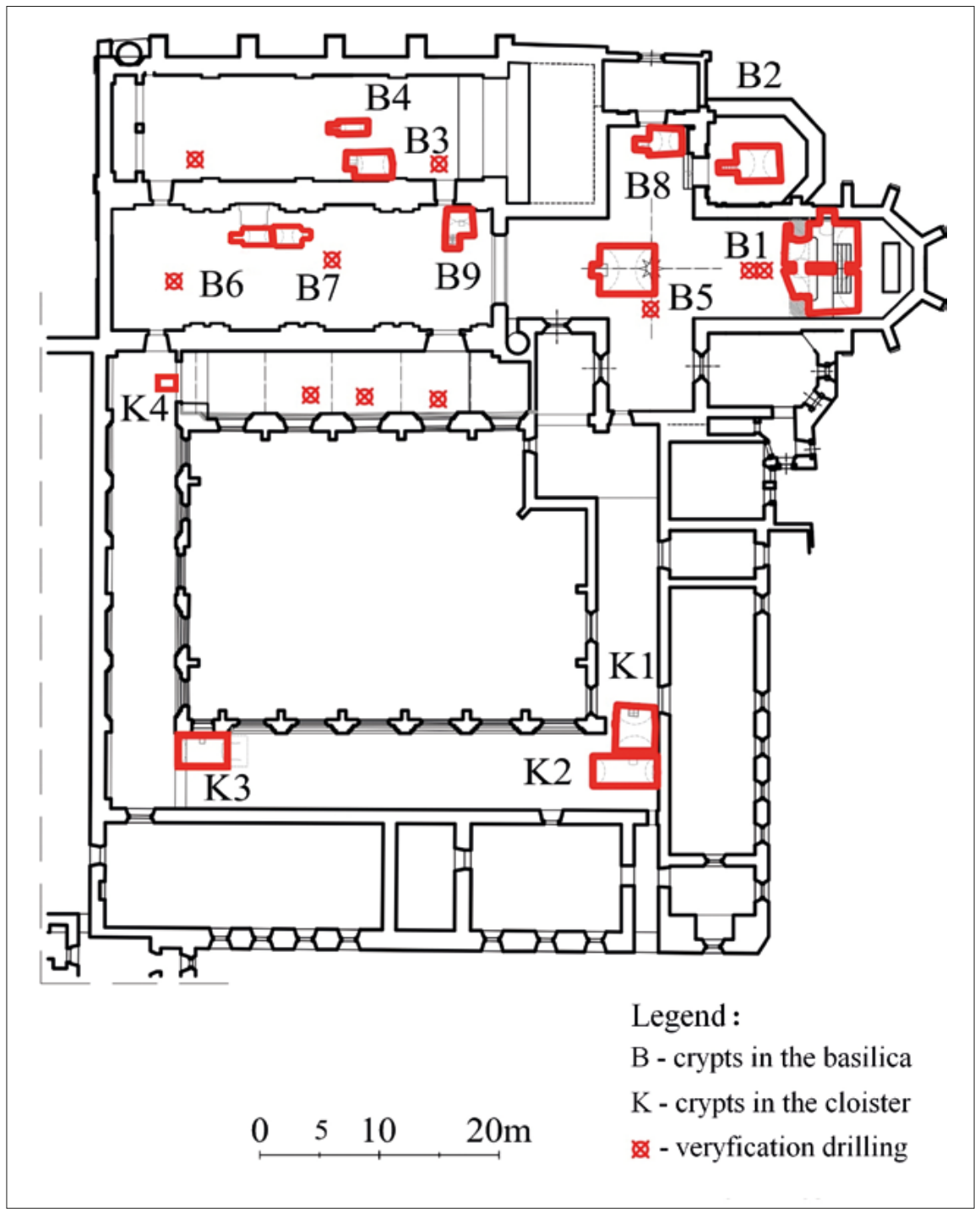

Fig. 1. The layout of the Church of Saint Francis of Assisi and the Franciscan monastery, with the location of crypts and boreholes (prepared by S. Cechosz, Ł. Holcer).

section of the basilica (the chancel, the transept, the nave, and the chapels) and in the cloisters (Eyczak et al. 2018: 357-372). The fixed furnishings of the church, meaning connected heavy pews, confessionals, choir stalls, and the scaffolding in some of the cloisters, slightly limited the extent of the survey. The results of investigations using three different devices were rather similar (Welc et al. 2020) 
and, after analysis of registered anomalies in sections and time sections, they allowed to identify crypt locations. However, the largest amount of information and high-resolution time sections were obtained thanks to the use of the Ground Explorer georadar manufactured by Mala/ABEM. The locations identified were compared with two archival plans $(1908,1922)$ of the church and the monastery, drawn up by Fr. Alojzy Karwacki, who marked the locations of all graves, tombs, crypts, altars, and epitaphs he was aware of in 1908 (Karwacki 1908; 1922: 543-545). Most of the crypts indicated on the plan were provisionally matched with the registered geophysical anomalies. Apart from that, comparison of non-invasive research results with preserved documents made it possible to find underground vaults not mentioned in archival sources, such as the crypts under the Chapel of the Passion of Christ ( $\mathrm{B}_{3}$ and $\mathrm{B}_{4}$ ).

The next stage involved confirmation of the location of underground vaults using an inspection camera, which was also to determine the state of preservation of the crypts and the coffins. Another purpose of such non-invasive research was to establish where the flooring had to be removed to get through to the crypts. It was very important as the Franciscan basilica is strictly protected, which is why only five floor tiles $(30 \times 30 \mathrm{~cm})$ could be removed at a time, and the place where the hole was made had to be covered with a tent.

Thanks to all these non-invasive methods, we were able to locate eighteen crypts (Fig. I). Apart from that, the location of four crypts was known thanks to gravestones covering them. Thirteen crypts were opened, but only twelve sepulchral vaults were investigated: nine in the basilica (BI-B9) and three in the cloisters $\left(\mathrm{KI}-\mathrm{K}_{3}\right)^{2}$.

The remaining underground stone vaults (9) could only be investigated using non-invasive methods, analysing and assessing them based on inspection camera images taken through small-diameter boreholes. Some of them were filled with rubble but the sepulchral function was confirmed in all cases.

Before the beginning of the exploration, the team of archaeologists came up with procedures that would ensure that all specialist analyses were correct and could be compared. This also allowed to maintain order and to bear in mind other tasks that were to be performed in all crypts later.

Before the exploration started, samples for microbiologists were collected and then - after the disinfection of the crypt - photographic and drawing documentation was drawn up. Then, thanks to modern technical solutions offered by ground $3 \mathrm{D}$ laser scanning, imaging measurement methods were employed to

2 The crypts under the floor of the basilica we entered were marked with the letter в and numbers from I to 9 in the order of opening. The crypts in the cloisters were marked with the letter $\mathrm{K}$ and numbers from I to 4 . The $\mathrm{K} 4$ crypt in the cloisters was full of bones and had served as an ossuary. 


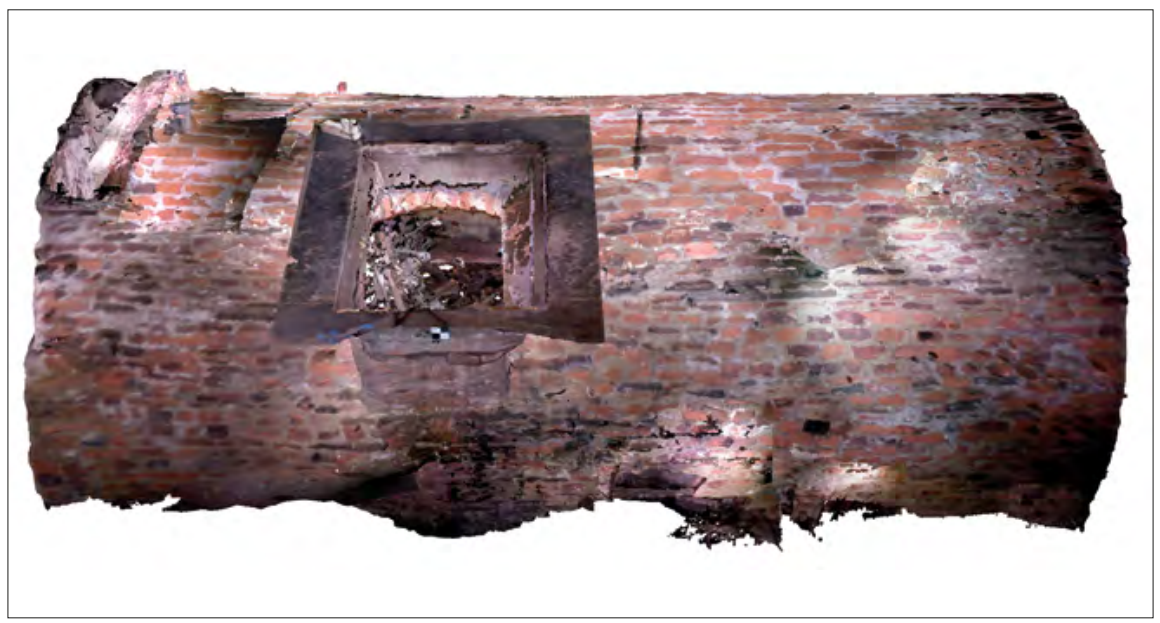

Fig. 2. A 3D model of the $\mathrm{K} 2 \mathrm{crypt}$ in the eastern wing of the cloisters (prepared by J. Curyło).

inventory the crypts, devised by two independent teams using different equipment and analysing the data obtained in different ways ${ }^{3}$.

The scanners used included: time-of-flight $\mathrm{Z}+\mathrm{F}$ Imager 5010C, Faro Focus 3D and Siso manufactured by FARO. In order to supplement and improve the image quality in some inaccessible crypts, a digital camera and photogrammetric 3D model rendering were used. Thanks to this, fully metric models were created offering complete, accurate rendering of the structure and the shape of the objects (Fig. 2), preserving their dimensions, proper location, and reproducing the smallest details, the size of bricks on the walls and the ceiling, decorative details of coffins (Fig. 3) as well as details of the clothing of the dead. The point clouds obtained provided a basis for further detailed analyses and can be used for various purposes. For example, they allowed to create an interactive virtual tour of the crypts that, as soon as the research ended, once again became inaccessible and covered with flooring.

Apart from that, the imaging measurement method was employed to inventory the whole church, thanks to which its detailed 3D model was created, allowing to prepare an animation showing the crypts and their layout.

After the end of the documentation work described above, coffins, burials, and goods were inventoried, and samples were collected to be analysed by various scientists (e.g. fragments of bones, fabrics, lace, and plants).

3 One team came from the AGH University of Science - Antoni Rzonca and Maciej Bernaś, the other team included Jakub Curyło from the Cybid company. 


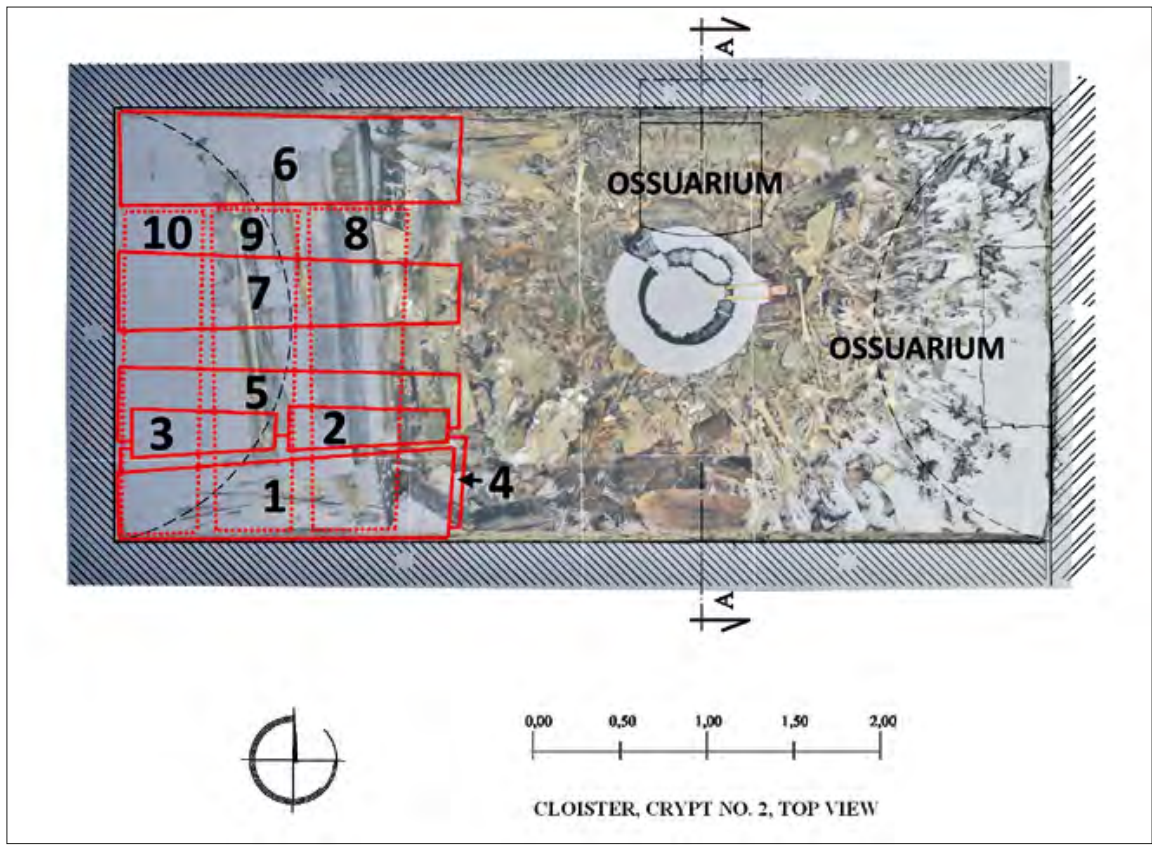

Fig. 3. The arrangement of burials in the K2 crypt located in the eastern wing of the cloisters, based on an orthoscan (prepared by J. Curyło).

\section{General research results}

Based on exploratory and non-invasive research, it was determined that the crypts under the Franciscan basilica had no dense spatial arrangement in architectural terms and they were not connected. Neither were they designed at the same time, which is why their layout seems rather chaotic. This is also indicated by the fact that crypts were built in places occupied by previous masonry structures for burying the dead. The location of a grave, as in any other church, depended on the rank and the financial situation of the dead. Most of the crypts found date back to the seventeenth and the eighteenth centuries. All are made of brick, with barrel vaults. Those buried under the floor of the Franciscan church included the founders of the church and the monastery, monks and nuns, members of eminent noble families, and wealthy citizens of Cracow.

In the crypts opened, the researchers found and inventoried 96 burials in 95 wooden painted (4I) or upholstered $(55)^{4}$ coffins (Fig. 4). In one case, in the B9 crypt, coffin II, the remains of two people, a man and a woman, were found. The

4 In the в2 crypt, there was a double coffin. 
woman's bones had probably been added when the crypt had been cleaned. In the $\mathrm{BI}$ crypt and in $\mathrm{KI}, \mathrm{K} 2$ and $\mathrm{K} 4$ crypts in the cloisters, apart from coffin burials, there were also ossuaries. The $\mathrm{K} 4 \mathrm{crypt}$ was filled with bones.

The number of burials was different depending on the crypt. This, to a large extent, resulted from different dimensions of the vaults. In a majority of cases, they had up to twenty coffins. Most burials (26) were found in the B5 crypt, while the B4 crypt under the floor of the Chapel of the Passion of Christ had only one burial. Due to the poor state of preservation, only some of the skeletons were subjected to anthropological analysis. There were $40 \mathrm{men}$, 44 women, and I 8 infants I children buried in the vaults. It was impossible to determine the sex of 24 skeletons. Most of the dead were lying in accordance with the Christian burial tradition, in anatomical supine position, along the east-west axis, with the head towards the west.

A significant problem during the research was the identification of the dead, so most of them remained unidentified. Names were only found on two coffins.

Under the chancel in the BI crypt, in coffin no. 2, the remains of guardian Reverentissimus Pater Magister Teofil Nowakowski were found, and in the B3 crypt, in coffin no. 2, under the floor of the Chapel of the Passion of Christ - the remains of 'Woiewodziwic Poznaski' (Poznań Voivode) Fran.[ciszek] Bętkoski, who died in 1789 . On other thirty-two coffins, initials, dates, and, in a few cases, also coats of arms $\left(B 2 \backslash_{I}\right.$ - Leliwa coat of arms, B3 $\backslash_{2}$ - Ostoja coat of arms, B6 $\backslash_{I}$, B6 $\backslash_{S}$ - probably Odyniec coat of arms, B8 $\backslash_{\mathrm{I}}$ - Jastrzębiec, B9 $\backslash_{\mathrm{I} 3}$ - probably Sas) were painted or imprinted with nails. Only in one case, the buried person was identified using

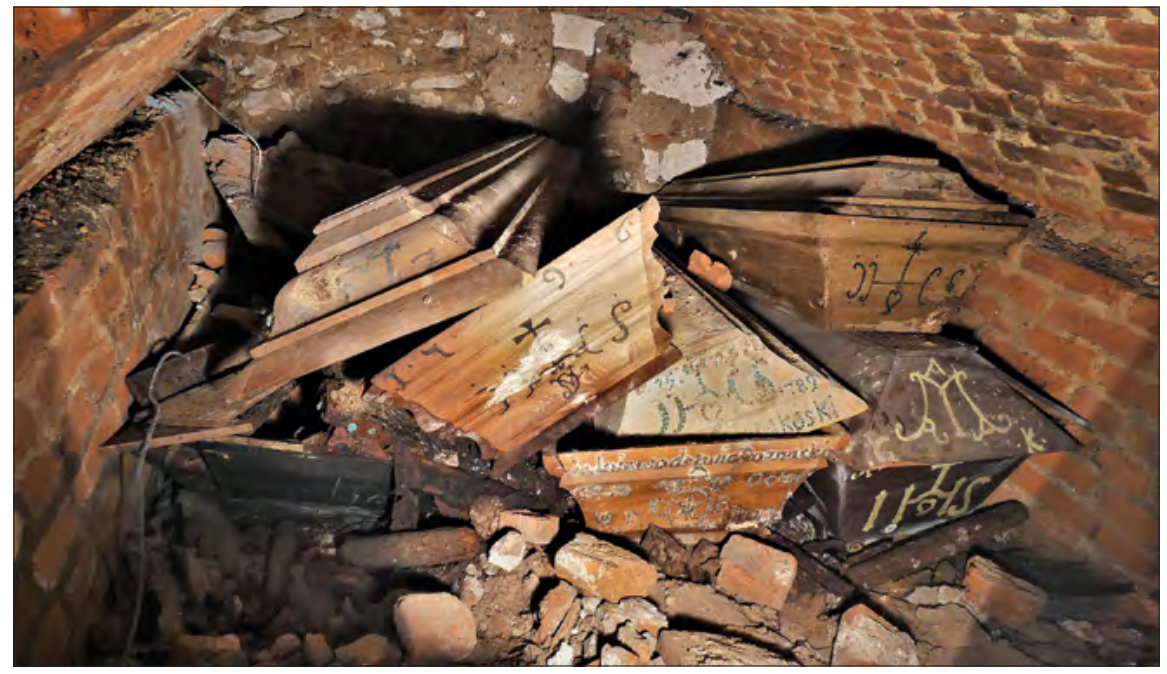

Fig. 4. Coffins from the в 3 crypt under the Chapel of the Passion of Christ (photograph by J. Curyło). 
archival sources based on the initials on the chest $\mathrm{Xww}$ : Rev. Wincenty Wyszkowski (the B9 crypt, burial I). When determining the identity of the dead, the researchers also tried to use the plans drawn up by Alojzy Karwacki in 1908 and 1922, where the monk marked the location of the crypts, with information who was buried in them: $\mathrm{BI}$ - the tomb of provincials, $\mathrm{B} 2$ - the grave of the Zborowski family, B3 and B4 - not marked on the plans, B5 - the grave of the Przytecki family, B6 - the grave of the Gielec family, B7 - unknown, B8 - the grave of the Brzechwa family, B9 - the grave of the Betchackifamily. When it comes to the identification of the crypts in the cloisters, the plans only provided information about the K2 crypt - presumably the grave of sisters of Saint Clare; rotten coffins, and the bodies have veils around their heads. However, when the crypt was opened, it turned out only the lay were buried there.

The coffins found in the Cracow crypts contained all kinds of goods. The largest collection included clothes of the lay and the clergy with accessories (13I) found in the case of 62 burials. The 74 items for the lay included shirts, a national Polish costume ${ }^{5}$, women's and children's dresses, an apron, trousers, and habits of members of the archbrotherhood. Most clothes were made of silk, with a few items of wool and linen preserved in small fragments. The clothing was analysed by costumists, and the fabrics were analysed by technical and technological specialists. Also the dyes used were analysed. The results indicate that the grave clothes were of different colours: red, blue, green, and yellow, with only a few black items.

Another large collection found in 46 chests consisted of pillows and mattresses (23). The dead were also given devotional items: scapulars (26), rosaries (26), crosses made of wood (17) and metal (8), medallions (17), rings (4), one holy picture, and a reliquary. Garlands of natural flowers were found in four graves of children and one of an adult woman. Bunches of fresh flowers were found in sixteen coffins.

To sum up, apart from the above information, an exceptional value of the research carried out in the Cracow crypts lies in the fact that one project allowed to conduct a very detailed non-invasive (georadar) investigation, testing the usefulness of different devices, and the results obtained could be correlated with the results of archaeological and architectural work. Based on that, apart from the location of the crypts, it was possible to register the remains of the foundation walls of old above-ground structures, which is important for the determination of architectural changes undergone by the church and the monastery.

5 The collection is represented by as many as 20 items: 13 żupans, 2 items of czechman, 2 pairs of trousers, a feryaz, a kontusz, and one national costume preserved in small fragments. 


\section{Bibliography}

Długosz J. (I864), Liber beneficiorum dioecesis cracoviensis, vol. III, Cracow.

Długosz J. (1973), Roczniki czyli kroniki stawnego Królestwa Polskiego, vol. III, Państwowe Wydawnictwo Naukowe, Warszawa.

Kantak K. (1937), Franciszkanie polscy, vol. I, I237-I5I7, Prowincja Polska oo. Franciszkanów, Kraków.

Karwacki A. (I908), Ołtarze dawne (przed I850) i teraźniejsze (I908 r.). Portrety i pomniki zaginione i dotąd istniejące. Groby i obrazy w kościele, kaplicach i na krużgankach o.o. Franciszkanów w Krakowie według najstarszych wizytacji, Inwentarza o. Wyszkowskiego z r. 1792 i stanu obecnego w 1908 (a working inventory, a manuscript).

Karwacki A. (1922), Inwentarz kościoła oo. Franciszkanów, [in:] Materiały do historii oo. Franciszkanów w Polsce, vol.xxiI (AFK, ref. no. E-I-22 of the monastic archive), p. $543-545$.

Labuda G. (1983), Kto byt fundatorem-zatożycielem klasztoru franciszkanów w Krakowie, [in:] J. Kłoczowski (ed.), Franciszkanie na ziemiach polskich, vol. I, Zakony franciszkańskie w Polsce, p. I, Franciszkanie w Polsce średniowiecznej, Prowincjałat oo. Ojców Franciszkanów Konwentualnych Prowincji św. Antoniego i bł. Jakuba Strepy, Lublin, p. 369-38I.

Łyczak M., Adamiec J., Skupień T., Małysa T., Groffik A. (2018), Georadar Surveys of the Flooring in the St. Francis of Assisi Basilica in Krakow, "Geology, Geophysics \& Environment", 44 (4), p. 357-372, https://doi.org/10.7494/geol.2018.44.4.357

Niewalda W., Rojkowska H. (2006), Zespót klasztorny Franciszkanów w Krakowie - relikty z XIII w., [in:] Z. Kliś (ed.), Studia z dziejów kościoła Franciszkanów w Krakowie, Polskie Towarzystwo Teologiczne. Sekcja Wydawnicza Wydawnictwo Unum, Kraków, p. 8I-I30.

Niewalda W., Rojkowska H. (2008), Średniowieczny kościót franciszkanów w świetle ostatnich badań, [in:] K. Ożóg, T. Gałuszka, A. Zajchowska (ed.), Mendykanci w średniowiecznym Krakowie, Wydawnictwo Esprit, Kraków, p. 27I-298.

Welc F., Łyczak M., Drążkowska A. (2020), Kompleksowe rozpoznanie metoda georadarowa (gpr) wnętrza bazyliki franciszkanów w Krakowie, [in:] A. Drążkowska (ed.), Krypty grobowe kościota pw. św. Franciszka z Asyżu w Krakowie w świetle badań interdyscyplinarnych, vol. I, Archeologia - Historia - Kostiumologia, Toruń (forthcoming).

\section{Summary}

\section{Research in the Crypts of the Church of Saint Francis of Assisi in Cracow}

The paper presents the results of archaeological research carried out from 2017 to 2018 in the Church of Saint Francis of Assisi in Cracow, funded by the National Science Centre. The aim of the work undertaken was to locate, inventory, and explore crypts, and to study in detail burials and grave goods. The paper discusses different devices, research methods, and procedures developed by the team and used to locate crypts. They allowed to find 
eighteen crypts in the church and four in the cloisters. All underground chambers were inventoried using 3D laser scanning. During research, ninety-six burials of the lay and the clergy, men, women, and children, were found.

Keywords: research in crypts, Cracow, funeral culture

\section{Streszczenie}

\section{Badania w kryptach kościoła św. Franciszka z Asyżu w Krakowie}

W artykule zaprezentowano wyniki badań archeologicznych prowadzonych w latach 2017-2018 w kościele św. Franciszka z Asyżu w Krakowie, które finansowane były przez Narodowe Centrum Nauki. Celem podjętych prac było zlokalizowanie, inwentaryzacja i eksploracja krypt grobowych oraz szczegółowe przebadanie pochówków wraz z wyposażeniem. Omówiono różne urządzenia użyte do poszukiwań krypt, metody badań i wypracowane przez zespół procedury. Dzięki nim odnaleziono osiemnaście krypt w kościele i cztery w krużgankach klasztoru. Wszystkie podziemne pomieszczenia zostały zinwentaryzowane za pomocą skaningu laserowego $3 \mathrm{D}$. W trakcie badań odnaleziono 96 pochówków osób świeckich i duchownych, mężczyzn, kobiet i dzieci.

Słowa kluczowe: badania w kryptach, Kraków, kultura funeralna

\section{Anna Drążkowska}

Nicolaus Copernicus University in Toruń

Institute of Archaeology

Poland

e-mail: annadr9@wp.pl 